\title{
GAMBARAN PENGETAHUAN PASANGAN USIA SUBUR TENTANG PENYAKIT MENULAR SEKSUAL DI DESA MATA ALLO DUSUN BERDIKARI I KABUPATEN GOWA TAHUN 2018
}

\author{
${ }^{1)}$ Nur Israyati , ${ }^{2}$ Eka Nurlina \\ STIKES HANG TUAH Pekanbaru
}

\begin{abstract}
INTISARI
Penyakit Menular Seksual (PMS) adalah penyakit-penyakit yang timbul atau ditularkan melalui hubungan seksual dengan manifestasi klinis berupa timbulnya kelainankelainan terutama pada alat kelamin. Berdasarkan profil dinas kesehatan provinsi sulawesi selatan tahun 2016 jumlah kasus HIV sebanyak 1030 orang, AIDS 578 orang, (Dinkes Sulawesi Selatan, 2016). Berdasarksan data awal ada 80 PUS di Desa Mata Allo Dusun Berdikari I dari observasi yang telah dilakukan dari 10 PUS 7 PUS mengatakan tidak mengetahui tentang PMS. Penelitian ini bertujuan untuk mengetahui pengetahuan pasangan usia subur tentang penyakit menular seksual. Penelitian ini menggunakan deskriptif observasional dengan metode pengambilan sampel accidental sampling pada semua pasangan usia subur di Desa Mata Allo, Dusun Berdikari 1 sebanyak 40 sampel, dari 28 Juli - 04 Agustus 2018. Jenis data menggunakan data primer yaitu meneliti dengan cara membagikan quesioner kepada responden dan quesioner di kembalikan kepada peneliti untuk diolah. Adapun hasil penelitian ini disajikan secara berurutan dalam bentuk tabel distribusi frekuensi persentase. Simpulan : responden yang tahu tentang PMS dikategorikan baik sebanyak 27 orang. Hal tersebut diakibatkan dari jumlah responden yang berpengetahuan baik berpendidikan menengah ke atas hal ini dikarenakan seringnya mengikuti penyuluhan dan mendapatkan informasi di media serta sering menjadi peserta seminar, sedangakan responden yang berpengetahuan kurang rata-rata berpendidikan menengah ke bawah dan kuranganya keingitahuaan tentang penyakit menular seksual. Diharapkan kepada para pasangan usia subur lebih aktif mencari informasi dari petugas kesehatan, media cetak dan mengikuti penyuluhan yang diberikan tenaga kesehatan.
\end{abstract}

Kata kunci : Pengetahuan, Pasang Usia Subur, Penyakit Menular Seksual 


\section{PENDAHULUAN}

Penyakit Menular Seksual (PMS) adalah penyakit-penyakit yang timbul atau ditularkan melalui hubungan seksual dengan manifestasi klinis berupa timbulnya kelainan-kelainan terutama pada alat kelamin (Kunoli F J, 2013).

Penyakit Menular Seksual (PMS) adalah penyakit yang penularannya terutama melalui hubungan seksual. WHO (2009) menyebutkan bahwa terdapat lebih kurang 30 jenis mikroba (bakteri,virus, dan parasit) yang dapat ditularkan melalui hubungan seksual. Kondisi yang paling sering ditemukan adalah infeksi gonorrhoeae, chlamydia, syphilis, trichomoniasis, chancroid, herpes genetalis, infeksi human immunodeficiency virus (HIV) dan hebatitis B (Masriadi, 2017) .

Prevaliensi penyakit menular seksual (PMS) diantarnya Gonore dan klamidia sebesar $178 \%$ dan sifilis $44 \%$,s sedangkan survei terpadu Biologis perilaku (STBP) kemenkes 2016, HIV pada tahun 2015 yaitu 30.935 orang, tahun 2016 sebanyak 41.250 orang, dan pada tahun 2017 yaitu 10.375 orang. Jumlah infeksi HIV tertinggi yaitu di DKI Jakarta sejumlah 46.758 orang, diikuti Jawa Timur sebanyak 33.043, Papua sebanyak 25.586, Jawa Barat sebanyak 24.650 orang, dan Jawa Tengah sebanyak 18.038 orang (STBP KenKes 2016).

Sedangkan jumlah kasus AIDS di Indonesia pada tahun 2015 sebanyak 7.185 orang, tahun 2016 sebanyak 7.491 orang, dan padu tahun 2017 sebanyak 673 orang. Jumlah AIDS terbanyak dilaporkan dari Jawa Timir sebanyak 17.014 orang, Papua 13.398 orang, DKI Jakarta sebanyak 8.769 orang, Bali sebanyak 6.824 orang, Jawa Tengah sebanyak 6.531 orang, Jawa Barat sebanyak 5.289 orang, Sumatera Utara sebanyak 3.897 orang, Sulawesi Selatan sebanyak 2.812 orang, Kalimantan Barat sebanyak 2.597 orang, dan NTT sebanyak 1.959 orang (Kemenkes RI, 2017).

Berdasarkan profil dinas kesehatan provinsi sulawesi selatan tahun 2016 jumlah kasus HIV sebanyak 1030 orang, AIDS 578 orang, (Dinkes Sulawesi Selatan, 2016).

Kasus penyakit menular seksual menurut kelompok resiko yang tertinggi adalah WPS sebanyak 2,024, sedangkan LSL (laki suka laki) sebanyak 96 kasus, pelanggan pekerja seks 50 kasus, pasangan resiko tinggi 44 kasus, pada tahun 2016 tercatat kasus penyakit menular seksual dikota makassar sebanyak 2,676 kasus, sedangkan HIV pada tahun 2016 yaitu sebanyak 773 kasus (561 kasus pada laki-laki dan 212 
kasus pada perempuan. Kasus baru HIV selama 3 tahun terakhir di Kota Makassar yaitu pada tahun 2014 sebanyak 705 kasus, tahun 2015 menurun menjadi 665 kasus, dan pada tahun 2017 mengalami peningkatan yaitu sebanyak 773 kasus. Menurut jenis kelamin, proporsi kasus baru HIV yaitu laki-laki dengan persentase $72.57 \%$ dan perempuan dengan persentase $27,43 \%$.

Berdasarkan data dari Bilogis P2PL Dinas Kesehatan Kota Makassar, kasus baru HIV pada tahun 2016 yaitu sebanyak 773 kasus (561 kasus pada lakilaki dan 212 kasus pada perempuan. Kasus baru HIV selama 3 tahun terakhir di Kota Makassar yaitu pada tahun 2014 sebanyak 705 kasus, tahun 2015 menurun menjadi 665 kasus, dan pada tahun 2017 mengalami peningkatan yaitu sebanyak 773 kasus. Menurut jenis kelamin, proporsi kasus baru HIV yaitu laki-laki dengan persentase $72.57 \%$ dan perempuan dengan persentase $27,43 \%$.

Menurut penelitian yang telah dilakukan Hendy Pratamaputra Hidayat tingkat pengetahuan siswa tentang penyakit menular seksual pada tingkat baik banyak 4 responden (9\%), tingkat cukup sebanyak 34 responden (79\%) dan tingkat kurang sebanyak 5 responden $(12 \%)$.

Berdasarksan data awal ada 80 PUS di Desa Mata Allo Dusun Berdikari
I dari observasi yang telah dilakukan dari 10 PUS 7 PUS mengatakan tidak mengetahui tentang PMS.

Dengan alasan iniah peneliti tertarik mengadakan penelitian dengan judul gambaran pengetahuan pasangan usia subur tentang penyakit menular seksual di desa Mata Allo Dusun Berdikari 1.

\section{METODE PENELITIAN}

Penelitin ini menggunakan metode deskriftif observasional dengan metode pengambilan sampel accidental sampling pada semua pasangan usia subur di Desa Mata Allo, Dusun Berdikari 1 sebanyak 40 sampel, dari 28 Juli - 04 Agustus 2018. Jenis data menggunakan data primer yaitu meneliti dengan cara membagikan quesioner kepada responden dan quesioner di kembalikan kepada peneliti untuk diolah. Adapun hasil penelitian ini disajikan secara berurutan dalam bentuk tabel distribusi frekuensi persentase.

\section{HASIL PENELITIAN}

1. Karakteristik responden menurut umur

\section{Tabel 1}

Distribusi Frekuensi Responden

Berdasarkan Umur Di Desa Mata Allo

Kab.Gowa Tahun 2018 


\begin{tabular}{|c|c|c|}
\hline Umur & Frekuensi (n) & $\begin{array}{c}\text { Persentase } \\
(\%)\end{array}$ \\
\hline $20-25$ & 10 & 25 \\
\hline $26-30$ & 13 & 32.5 \\
\hline $31-35$ & 7 & 17.5 \\
\hline $36-40$ & 9 & 22.5 \\
\hline Total & 40 & 100.0 \\
\hline
\end{tabular}

Sumber : Data Primer 2018

Tabel 1 menunjukan bahwa jumlah responden terbanyak ada pada kelompok umur 26-30 tahun yaitu sebanyak 13 orang $(32,5 \%)$, sedangkan kelompok umur 20-25 sebanyak 10 orang (25\%), kelompok umur 31-35 sebanyak 7 orang $(17,5 \%)$, dan kelompok umur 36-40 ada sebanyak 9 orang $(22,5 \%)$, sedangkan kelompok umur 41-45 ada 1 orang $(2,5 \%)$.

2. Karakteristik menurut pendidikan

Tabel 2

\section{Distribusi Frekuensi Responden}

Berdasarkan Pendidikan Di Desa Mata

Allo Kab.Gowa Tahun 2018

\begin{tabular}{|c|c|c|}
\hline Pendidikan & $\begin{array}{c}\text { Frekuensi } \\
(\mathrm{n})\end{array}$ & $\begin{array}{c}\text { Persentase } \\
(\%)\end{array}$ \\
\hline Tidak Sekolah & 2 & 5,0 \\
\hline SD & 7 & 17.5 \\
\hline SMP & 4 & 10,0 \\
\hline SMA & 15 & 37.5 \\
\hline $\begin{array}{c}\text { Perguruan } \\
\text { Tinggi }\end{array}$ & 12 & 30,0 \\
\hline Total & 40 & 100.0 \\
\hline
\end{tabular}

Sumber : Data Primer 2018
Tabel 2 menunjukan bahwa jumlah responden terbanyak ada pada kelompok pendidikan SMA sebanyak 15 orang (37,5\%), perguruan tinggi sebanyak 12 orang $(30,0 \%)$, SD sebanyak 7 orang (17,5\%), tidak sekolah 2 orang (5,0\%), SD sebanyak 7 orang $(17,5 \%)$, SMP 4 orang $(10,0 \%)$, sedangkan yang tidak sekolah sebanyak 2 orang.

3. Karakteristik menurut pengetahuan

Tabel 3

\section{Distribusi Frekuensi Responden}

Berdasarkan Pengetahuan Di Desa

Mata Allo Kab.GowaTahun 2018

\begin{tabular}{|c|c|c|}
\hline Pengetahuan & Frekuensi (N) & $\begin{array}{c}\text { Persentase } \\
(\%)\end{array}$ \\
\hline Baik & 27 & 67,5 \\
\hline Kurang & 13 & 32.5 \\
\hline Total & 40 & 100.0 \\
\hline
\end{tabular}

Sumber : Data Primer 2018

Tabel 3 menunjukkan bahwa jumlah responden yang berpengetahuan baik sebanyak 27 orang $(67,5 \%)$, dan 13 orang $(32,5 \%)$ berpengetahuan kurang.

\section{PEMBAHASAN}

1. Umur

Berdsarkan hasil penelitian yang dilakukan di Desa Mata Allo dari 40 responden kelompok umur 26-30 tahun yaitu sebanyak 10 orang (25\%), kelompok umur 26-30 tahun yaitu sebanyak 13 orang (32,5\%), kelomok 
umur 31-35 tahun yaitu sebanyak 7 orang $(17,5 \%)$, sedangkan kelompok umur 3640 tahun yaitu sebanyak 9 orang $(22,5 \%)$. Dari karakteristik umur di simpulkan bahwa kelompok umur 26-30 tahun memiliki frekuensi paling tinggi dari kelompok umur 31-35 tahun memiliki frekuensi rendah.

\section{Pendidikan}

Berdasarkan hasil penelitian dari 40 responden yang tidak sekolah 2 orang (5, 0\%), kelompok pendidikan SD 7 orang (17,5\%), kelompok pendidikan SMP 4 orang $(10,0 \%)$, sedangkan pendidikan SMA ada sebanyak 15 orang $(37,5 \%)$, kelompok pendidikan perguruan tinggi 12 orang $(30,0 \%)$. Dari kelompok pendidikan yang memiliki frekuensi paling tinggi SMA sebanyak 15 orang dan yang paling rendah sekolah ada 2 orang.

\section{Pengetahuan}

Berdasarkan hasil penelitian dari 40 responden, responden yang memiliki pengetahuan baik yaitu 27 orang $(67,5 \%)$, sedangkan responden memiliki pengetahuan kurang yaitu 13 orang $(32,5 \%)$.

Berdasarkan hasil penelitian dari 40 responden didapatka yang berpengetahuan baik tentang penyakit menular seksual sebanyak 27 rsponden
$(67,5 \%)$ dan 13 responden $(32,5 \%)$ yang berpengetahuan kurang hal ini disebabkan jumlah berpengetahuan baik lebih banyak yang kurang, hal ini karenakan seringnya mengikuti penyuluhan dan mendapatkan informasi di media serta rata-rata pendidikan responden menengah dan perguruan tinggi dimana yang SMA sebanyak 15 orang dan perguruan tinggi sebanyak 12 orang.

Sedangkan, yang berpengetahuan kurang sebanyak 13 responden disebabkan jarangnya mengikuti kegiatan penyuluhan atau seminar. Dan rata-rata pendidikan responden menengah kebawah bahkan ada yang tidak pernah sekolah sama sekali.

Semakin tinggi pendidikan seseorang maka akan menambah pengetauan ibu tentang PMS sebaliknya semakin rendah pendidikan maka semakin kurang pengetahuan tentang PMS dan ibu selalu mencari tahu di media sosial tentang PMS sehingga ibu tahu mengenai PMS. .

Hal ini sejalan dengan penelitian yang telah dilakukan oleh Siti Patonah dkk (2014), pengetahuan pasangan usia subur dipengaruhi oleh pendidikan dan keinginan dalam mengetahui dan mencari informasi tentang penyakit menular seksual (PMS). 
Menurut natodmojo (2005) dalam Ayu Putri Ariani (2014) Pengetahuan (knowledge) merupakan hasil tahu, dan ini terjadi setelah orang melakukan pengindaran terhadap objek tertentu. Pengindaraan panca indera manusia yaitu indera penghliatan, pendengaran, penciuman, rasa dan raba. Sebagian besar pengetahuan manusia diperoleh melalui mata dan telinga, yaitu proses melihat dan mendengar. Selain itu proses pengalaman dan proses belajar dalam pendidikan formal maupun informal. Pengalaman disini berkaitan dengan umur dan pendidikan individu. Pendidikan yang tinggi, maka pengalaman akan lebih luas, sedangkan semakin tua umur seseorang maka pengalamannya akan semakin banyak (Lestari T, 2015, hal 5-6) (Marmi,2016).

Peneliti berasumsi dan dilihat berdasarkan data yang telah diperoleh dapat diketahui bahwa pendidikan pasangan usia subur sangat mempengaruhi tentang penyakit menular seksual, selain itu dapat juga dilihat dari segi umur karena pengalaman pasangan usia subur lebih luas atau pernah menjadi peserta penyuluhan tentang penyakit menular seksual (PMS). Sedangkan yang kurang pengetahuannya tentang penyakit menular seksual (PMS) dipengaruhi dari segi pendidikan rendah dan tidak ada pengalaman menjadi peserta penyuluhan tentang penyakit menular seksual (PMS).

\section{KESIMPULAN}

Dari hasil penelitian yang berjudul “ Gambaran Pengetahuan Pasangan Usia Subur (PUS) Tentang Penyakit Menular Seksual Di Desa Mata Allo Dusun Berdikari I Tahun 2018" dapat disimpulkan bahwa responden yang tahu tentang PMS dikategorikan baik sebanyak 27 orang. Hal tersebut diakibatkan dari jumlah responden yang berpengetahuan baik berpendidikan menengah ke atas hal ini dikarenakan seringnya juga mengikuti penyuluhan dan mendapatkan informasi di media serta sering menjadi peserta seminar, sedangakan responden yang berpengetahuan kurang rata-rata berpendidikan menengah ke bawah dan kuranganya keingitahuaan tentang penyakit menular seksual.

\section{SARAN}

\section{Bagi Responden}

Diharapkandengan adanya penelitian ini, para pasangan usia subur lebih aktif mencari informasi dari petugas kesehatan, media cetak dan mengikuti penyuluhan yang diberikan tenaga kesehatan. 
2. Bagi Peneliti

Diharapkan bagi peneliti selanjutnya hasil penelitian ini dapat bermanfaat dan dapat digunakan sebagai bahan atau referensi pembanding bagi penelitian selanjutnya.

3. Bagi Institusi

Diharapkan lebih mengenbangkan penelitian yang lebih lanjut tentang peberian kolostrum pada bayi baru lahir sehingga dapat dijadikan referensi dan bahan bacaan.

4. Bagi Pelayanan Kesehatan Diharapkan bagi bidan atau petugas kesehatan lainnya dapat meingkatkan informasi-informasi atau penyuluhan kepada pasangan usia subur tentang penyakit menular seksual.

DAFTAR PUSTAKA
Ariani Putri Ayu. 2014. Aplikasi Meodologi Penelitian Kebidanan Dan Kesehatan Reproduksi. Nuha Medika:Yogyakarta

Hidayat Pratamaputra Hidayat 2014, Tingkat pengetahuan Tentang Penyakit Menular Seksual Pada Siswa. Jurnal Media Medika Muda:Semarang

Katiandagho Desmon, SST., M.Kes.. 2015. Epidemiologi HIV-AIDS. Penerbit IN MEDIA:Bogor

Kunoli, Firdaus J. 2013. Epidemiologi Penyakit Menular. CV. Trans Info Media : Jakarta Timur

Lestari Titik, S.Kep. 2015. Kumpulan Teori Untuk Kajian Pustaka Penelitian Kesehatan. Nuha Medika:Yogyakarta

Marmi. 2016. Pelayanan KB. Pustaka Pelajar:Yogyakarta 